\title{
Dermoscopy of Bowen's disease: pigmented variant on the penis
}

\author{
Dermatoscopia da doença de Bowen: variante pigmentada no pênis
}

\author{
Priscila Ishioka ${ }^{1}$ \\ Nilceo Schwery Michalany ${ }^{2}$
}

\author{
Sérgio Yamada ${ }^{1}$ \\ Sérgio Henrique Hirata ${ }^{3}$
}

\begin{abstract}
Pigmented Bowen's disease (PBD) is a variant of squamous cell carcinoma in situ and represents less than $2 \%$ of cases of Bowen's disease. It is characterized by a sharply demarcated, pigmented plaque with a scaly or crusted surface on intertriginous and genital areas. The authors describe a case of PBD on the penis and analyze the dermoscopic aspects of this type of lesion.

Keywords: Bowen's disease; Carcinoma, squamous cell; Dermoscopy; Neoplasms, squamous cell

Resumo: A doença de Bowen Pigmentada (DBP) é uma variante do carcinoma espinocelular in situ e compreende menos de $2 \%$ dos casos da Doença de Bowen. Apresenta-se como placa pigmentada, hiperqueratósica, delimitada, localizada em áreas intertriginosas e anogenital. Os autores descrevem um caso de DBP no pênis e abordam os aspectos dermatoscópicos dessa lesão.

Palavras-chave: Carcinoma de células escamosas; Dermoscopia; Doença de Bowen; Neoplasias de células escamosas
\end{abstract}

Pigmented Bowen's disease (PBD) is a rare dermatosis and accounts for less than $2 \%$ of Bowen's disease (BD) cases. ${ }^{1,2}$ Differential diagnoses for PBD comprise pigmented actinic keratosis, solar lentigo, seborrheic keratosis, melanocytic nevus, pigmented basal cell carcinoma, Bowenoid papulosis, and melanoma. Clinically, a pigmented, hyperkeratotic, welldemarcated plaque is generally observed on intertriginous and genital areas.

The pigmented variant of $\mathrm{BD}$ is characterized by the presence of abundant melanin pigment in the cytoplasm of atypical keratinocytes, namely, in the basal layer, due to hyperfunction and a slight increase in the number of melanocytes, which are typical. In addition, it is characterized by the presence of melanophages in the papillary dermis, associated with his- tological features of squamous cell carcinoma in situ. Little is known about the mechanism of pigmentation of BD. Neoplastic cells are considered to be capable of producing cytokines that induce melanocyte proliferation and melanin production. Hyperpigmentation of anogenital PBD may result from elevated temperature or simply from the more pronounced pigmentation usually found in this region. ${ }^{3}$

The authors describe dermoscopic aspects of PBD on the penis of a 50-year-old Caucasian male (Figure 1).

Dermoscopic examination revealed the presence of brown dots arranged in linear fashion, a structureless hypopigmented central area, an irregular brown area in the upper pole, and gray blotches (Figure 2).

\footnotetext{
Received on 20.07.2011.

Approved by the Advisory Board and accepted for publication on 16.11.2011.

Work conducted at the Department of Dermatology at Escola Paulista de Medicina - Federal University of Sao Paulo (EPM-UNIFESP) - Sao Paulo (SP), Brazil. Conflict of interest: None

Financial funding: None

MD, Department of Dermatology, Federal University of Sao Paulo (Universidade Federal de Sao Paulo - UNIFESP) - Sao Paulo (SP), Brazil.

MD, Department of Pathology, Federal University of Sao Paulo (UNIFESP) - Sao Paulo (SP), Brazil.

PhD, Department of Dermatology, Federal University of Sao Paulo (UNIFESP) - Sao Paulo (SP), Brazil.

(C)2012 by Anais Brasileiros de Dermatologia
} 


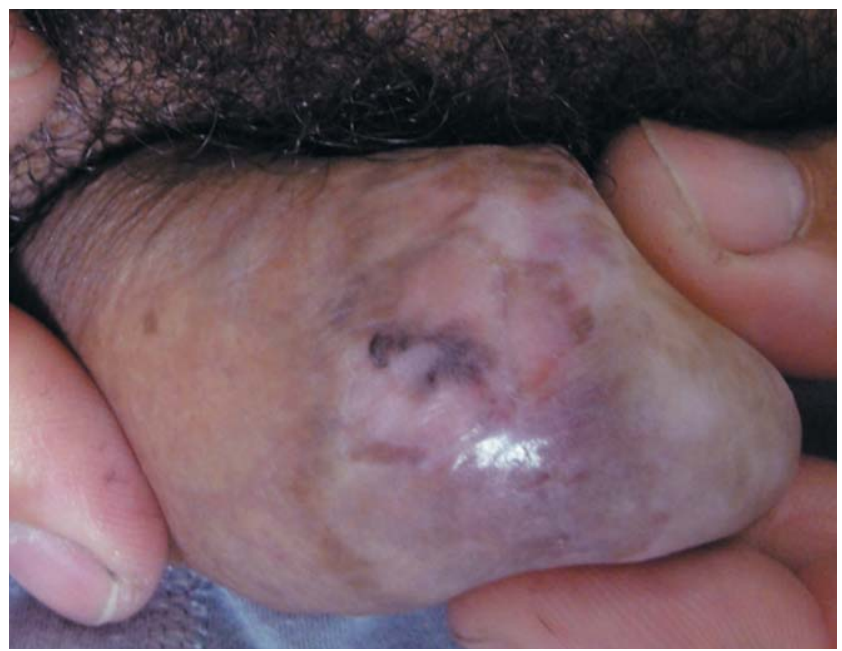

FIGURE 1: Dermoscopy of Bowen's disease: pigmented variant on the penis. Pigmented Bowen's disease: irregular, black spot with 1 $\mathrm{cm}$ in diameter on the glans penis and prepuce

Clinical and dermoscopic examination of a pigmented lesion on the penis allowed the following hypotheses: melanoma, pigmented Bowen's disease, melanocytic nevus, simple lentigo, and hypermelanosis.

The dermoscopic pattern of melanocytic nevi on this region is characterized by the presence of pigment network, globules, and streaks. Lentigines present a fine, delicate, and regular network. Dermoscopy of hypermelanosis on the mucosa presents a homogeneous brown area or fine regular lines in a parallel pattern. Occasionally, it may mimic the dermoscopy of a melanoma. In these cases, mucosal melanosis presents variegated pigmentation asymmetry of structures and irregular borders. Melanoma of

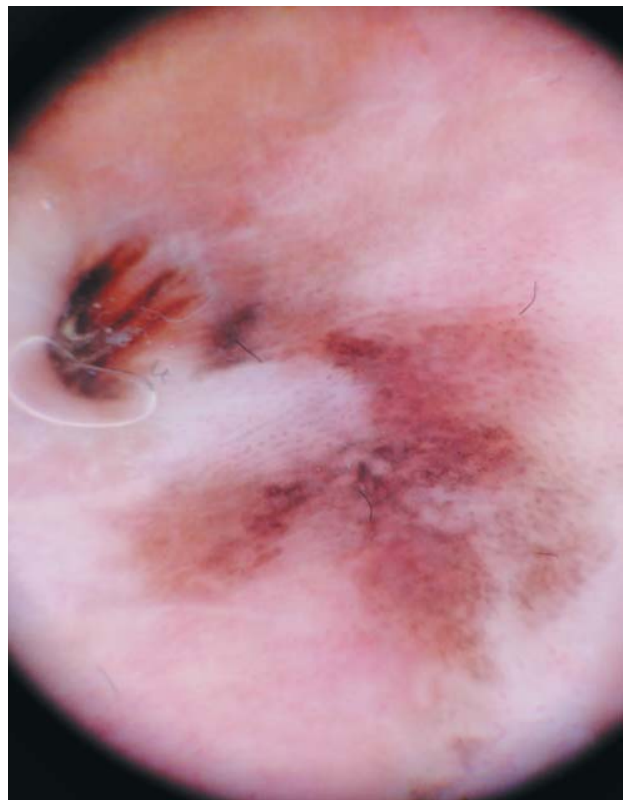

Figure 2:

Dermoscopy of Bowen's disease: pigmented variant on the penis.

Dermoscopy of Pigmented Bowen's disease on the penis. Presence of brown dots arranged in linear fashion and of a structureless hypopigmented area the penis is rare and accounts for $0.2 \%$ of all cutaneous melanomas. Dermoscopy of this melanoma is characterized by irregular pigmentation, linear vascular structures, multicomponent pattern, presence of veil, streaks, and regression structures. ${ }^{4-6}$

Dermoscopic appearance of BD was firstly described in 2004 by Argenziano et al.,' who observed that the presence of glomerular vessels was a suggestive finding of $\mathrm{BD}$. More recently, the presence of structureless, hypopigmented areas with brown or gray dots arranged in linear fashion and glomerular vessels, also arranged in linear fashion, was described as a suggestive finding of PBD (Table 1). ${ }^{8}$

An excisional biopsy was performed, and its pathological report revealed pigmented squamous cell carcinoma in situ (pigmented Bowen's disease), characterized by remarkable atypia and anaplasia of cells from the mucous malpighian body with cellular loss of polarity and presence of some dyskeratotic cells, besides a pronounced, irregular increase in melanin pigmentation in keratinocytes, both in the basal and squamous layers. Melanocytes slightly increased in number with clear dendrites and thickened granular, cornified layers were also observed (Figure 3 and 4).

$\mathrm{BD}$ is defined as a form of squamous cell carcinoma in situ. It is a distinct clinicopathologic entity of the skin and mucocutaneous junction.

PBD commonly presents as a hyperpigmented, sharply demarcated plaque with a surface that may be velvety, verrucous, or flat and affects intertriginous and genital areas. Scaling and erosions may be present as well. The lesions are generally asymptomatic; however, they may cause pruritus or burning pain.

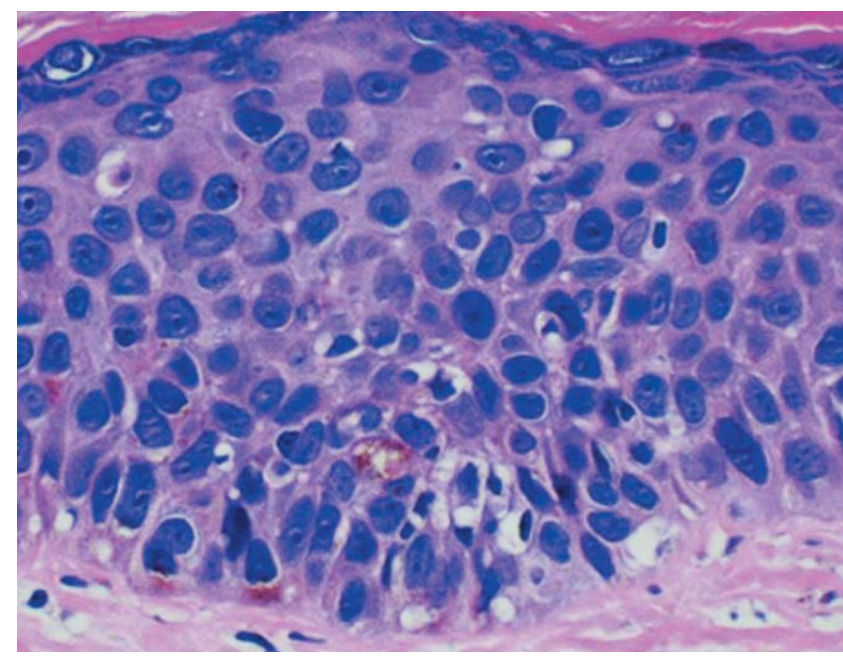

FigurE 3: Dermoscopy of Bowen's disease: pigmented variant on the penis. HE staining. Magnification x200 
TABLE 1: Dermoscopic features of PBD and findings of the case described

\begin{tabular}{ll}
\hline Dermoscopic features of PBD & Dermoscopic findings of the case described \\
\hline Multicomponent pattern & Yes \\
Atypical (glomerular) vascular structures & No \\
Absence of pigmented network or presence of pseudo-network & Yes \\
Irregular, diffuse pigmentation or pigmented blotches & Yes \\
Hypopigmented, structureless areas & Yes \\
Brown or gray dots arranged in linear fashion & Yes \\
\hline
\end{tabular}

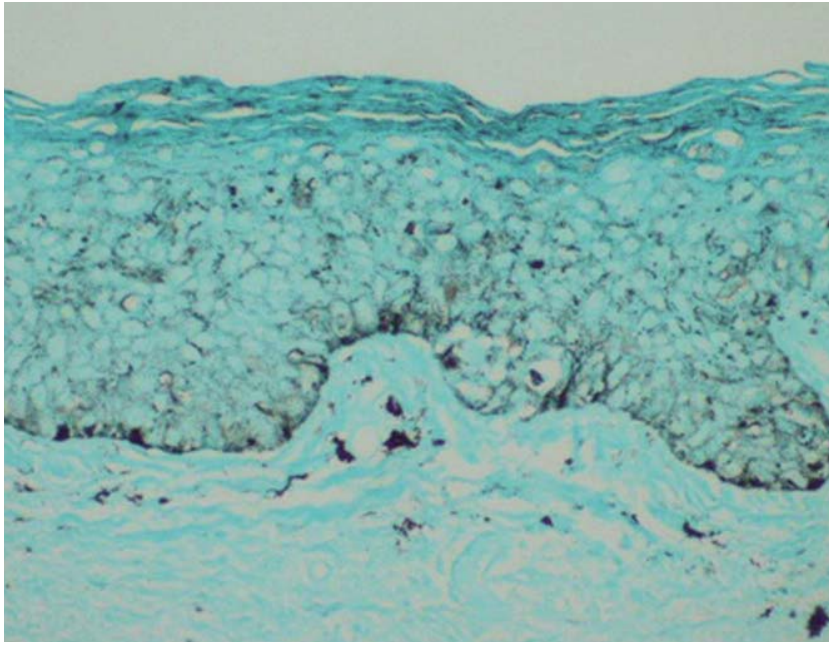

FIGURE 4: Dermoscopy of Bowen's disease: pigmented variant on the penis. Masson-Fontana staining. Magnification x200
Erythroplasia de Queyrat usually presents as one or more red, moist plaques on the mucosal surfaces of the glans, which may spread to the inner aspect of the prepuce.

Genital Bowen's disease and Erythroplasia de Queyrat are usually found in elderly men, being present on the follicle bearing skin and the mucosa of the penis (glans or prepuce), respectively. ${ }^{9-10}$

In the case described, the patient presented a dark brown plaque on the glans and prepuce. Due to the clinical and pathological characteristics of the lesion, the authors decided to classify it as pigmented Bowen's disease.

The authors emphasize the importance of using a dermoscope to diagnose suspicious pigmented lesions and reinforce the relevance of its use in the differential diagnosis with melanoma and hypermelanosis.

\section{REFERENCES}

1. Ragi G, Turner MS, Klein LE, Stol HL Jr. Pigmented Bowen's disease and review of 420 Bowen's disease lesions. J Dermatol Surg Oncol. 1988;14:765-9.

2. Papageorgiou PP, Koumarianou AA, Chu AC. Pigmented Bowen's disease. Br J Dermatol. 1998;138:515-8.

3. Krishnan R, Lewis A, Orengo IF, Rosen T. Pigmented Bowen's disease (squamous cell carcinoma in situ): a mimic of malignant melanoma. Dermatol Surg. 2001;27:673-4.

4. Betti R, Menni S, Crosti C. Melanoma of the glans penis. Eur J Dermatol. 2005;15:113-5.

5. Mannone F, De Giorgi V, Cattaneo A, Massi D, De Magnis A, Carli P. Dermoscopic features of mucosal melanosis. Dermatol Surg. 2004;30:1118-23.

6. Cameron A, Rosendahl C, Tschandl P, Riedl E, Kittler H. Dermoscopy of pigmented Bowen's disease. J Am Acad Dermatol. 2010;62:597-604.

7. Argenziano G, Zalaudek I, Corona R, Sera F, Cicale L, Petrillo G, et al. Vascular structures in skin tumors. A dermoscopy study. Arch Dermatol. 2004;140:1485-9.

8. Bugatti L, Filosa G, De Angelis R. Dermoscopy observation of Bowen's disease. J Eur Acad Dermatol Venereol. 2004;18:572-4.
9. Bleeker MC, Heideman DA, Snijders PJ, Horenblas S, Dillner J, Meijer CJ. Penile cancer: epidemiology, pathogenesis and prevention. World J Urol. 2009;27:141-50.

10. Leto MG, Santos Jr GF, Porro AM, Tomimori J. Human papillomavirus infection: etiopathogenesis, molecular biology and clinical manifestations. An Bras Dermatol. 2011;86:306-17.

How to cite this article: Ishioka P, Yamada S, Michalany NS, Hirata SH. Dermoscopy of Bowen's disease: pigmented variant on the penis. An Bras Dermatol. 2012;87(3):482-4. 